\title{
Characterization of Injury Caused by Edessa meditabunda (F.), Chinavia impicticornis (Stål), and Piezodorus guildinii (West.) (Hemiptera: Pentatomidae) to Soybean
}

\author{
PE HusCH ${ }^{1,2}$, MCN de OLIVEIRA ${ }^{2}$, DR SOSA-Gómez ${ }^{2}$ \\ ${ }^{1}$ Univ Federal do Paraná, Curitiba, PR, Brasil \\ ${ }^{2}$ Embrapa Soja, Londrina, PR, Brasil
}

\section{Keywords}

Glycine max, growth stages, population levels

\section{Correspondence}

PE Husch, Embrapa Soja, Caixa Postal 231, 86001-970 Londrina, PR, Brasil: patihusch@gmail.com

Edited by Jorge B Torres - UFRPE

Received 16 May 2013 and accepted 4 March 2014

Published online: 15 April 2014

(C) Sociedade Entomológica do Brasil 2014

\begin{abstract}
Field cage trials were carried out in Ponta Grossa, Paraná, season 2010/2011, aiming to characterize and evaluate the injury caused by Edessa meditabunda (F.), Chinavia impicticornis (Stål), and Piezodorus guildinii (West.) (Hemiptera: Pentatomidae) to soybean. Non-infested plants were compared with infested plants with 2 and 3 adults $/ \mathrm{m}$ (number of adult specimens per linear meter) at the R5.1-R9, R5.3-R9, R6-R9, and R7-R9 soybean growing stages. The following variables were analyzed: foliar retention, seed germination, and injury levels estimated by the tetrazolium test. Foliar retention index ranged from 2.3 to 4.1 in plants infested with $P$. guildinii and from 2.6 to 3.3 in plants infested with E. meditabunda and C. impicticornis, respectively. The lowest seed germination ranged from 66.5 to $76.5 \%$ and was observed in seeds from plants infested with 2 adults of C. impicticornis at R5.3-R9 and 3 adults of $P$. guildinii (R5.1-R9) and E. meditabunda (R7-R9). The highest average percentage of injury level for seeds occurred with seeds from plants infested at R5.1 with 2 or 3 adults $/ \mathrm{m}$ of P. guildinii, ranging from 22.6 to $25.0 \%$ and from 63.6 to $68.0 \%$ in the first and second trials, respectively. Edessa meditabunda caused the highest damage to the seeds of plants infested at R7 (34.0 and $41.4 \%)$, and 2 adults $/ \mathrm{m}$ of $\mathrm{C}$. impicticornis caused the highest number of damaged seeds $(54.0 \%)$ in plants infested at R6. Although both species were less harmful than $P$. guildinii, they could be a constraint factor for grain and seed commercialization.
\end{abstract}

\section{Introduction}

Although several pests attack soybean crops, seed-feeding stink bugs (Hemiptera: Pentatomidae) are among the most harmful to plant development and seed quality (CorrêaFerreira \& Panizzi 1999). These insects are known to cause direct injury through punctures in seeds and pods, as well as indirect injury since the wounds inflicted by their feeding activities allow the invasion of pathogens or foliar retention associated with delayed plant maturation (Panizzi et al 1979, Sosa-Gómez \& Moscardi 1995, Depieri \& Panizzi 2011).
In the last few years, the occurrence of high populations of stink bugs in the beginning of the soybean growing season may have been favored by the disseminated use of early sowing cultivars and high temperatures in the central region of the state of Paraná, as observed for Nezara viridula (L.) (Yukawa et al 2007). These facts, in addition to failures in control due to insecticide resistance, have made stink bug population management more difficult (Sosa-Gómez \& Silva 2010).

The oligophagous stink bug Piezodorus guildinii (West.) rapidly adapted to the soybean crop and is now spread throughout the soybean area in Brazil (Panizzi et al 2012). 
The occurrence of Edessa meditabunda (F.) in soybean is not as frequent as that of $P$. guildinii, but the former feeds on pods and can also injure the stems, causing dark lesions, which can lead to important losses to the plants (Galileo \& Heinrichs 1979). Edessa meditabunda is also originally from the Neotropical region. In Brazil, it is found from the state of Pará, the Midwest region of the country to the state of Rio Grande do Sul (Krinski \& Pelissari 2012, Panizzi et al 2012). This species has become more important in the last few years, causing injury to lettuce, chicory, rattlepod, and, occasionally, significant losses to soybean (Golin et al 2011, Krinski et al 2012, Krinski 2013).

The genus Chinavia Orian (1965), previously considered a subgenus of Acrosternum Fieber, currently encompasses over 70 described species distributed in the Afrotropical, Nearctic, and Neotropical regions (Schwertner \& Grazia 2007). It is one of the most widely distributed genera of Pentatominae, and many of its species are pests of Fabaceae, including soybean (Schwertner \& Grazia 2007). One of the most abundant species of Chinavia found in soybean is Chinavia impicticornis (Stål), previously referred to as Acrosternum impicticorne (Panizzi 2002). This species has been observed attacking a variety of plant species of agricultural importance (Schwertner \& Grazia 2007).

However, little is known about the injury caused by E. meditabunda and C. impicticornis. To the best of our knowledge, only two reports on $E$. meditabunda injury have been published (Galileo \& Heinrichs 1979, Silva et al 2012). Stink bugs (Pentatomidae) differ in their potential to damage soybean seeds (Depieri \& Panizzi 2011), and the critical period of their attack spans from the beginning pod (R3) to full pod (R4) and beginning seed (R5.1) (Panizzi et al 1979, CorrêaFerreira \& Panizzi 1999). Therefore, the objective of this study was to determine the quantitative and qualitative differences between the injury caused by the stink bugs E. meditabunda and C. impicticornis, compared to the already known injury caused by $P$. guildinii, to soybean plants infested at three different periods.

\section{Material and Methods}

Field cage trials were carried out during the season 2010/2011 at the Fazenda Escola Capão da Onça (FESCON), Universidade Estadual de Ponta Grossa (UEPG) (25 $05^{\prime} 33^{\prime \prime S}$, $50^{\circ} 03^{\prime} 48^{\prime \prime} \mathrm{W} ; 1,025 \mathrm{~m}$ a.s.l.). The field cages were made using two iron U-shaped structures (1.2 $\mathrm{m}$ high $\times 1.0 \mathrm{~m}^{2}$ area) covered with tulle and installed in a no-tillage area at the beginning of the reproductive phase (R1). The row spacing was $0.45 \mathrm{~m}$ and around 15 plants/m were planted.

The trial with $E$. meditabunda and $P$. guildinii used the soybean cultivar NK 3363 (Syngenta do Brazil, SP) sown on November 12, 2010, while the harvest was on April 8, 2011 (cycle of 147 days). For the trial with C. impicticornis and $P$. guildinii, the same soybean cultivar was sown on December 16, 2010 and harvested on May 12, 2011 (cycle of 150 days). Phenological soybean stages were characterized according to Yorinori (1996) after Ritchie et al (1982). All the stink bug species were kept in the laboratory until infestation. Dead insects were daily replaced, and the eggs laid were removed every day.

A completely randomized design was used in both trials. In the first trial, a $2 \times 3 \times 3 \times 4$ factorial arrangement was used: two stink bug species (E. meditabunda and $P$. guildinii) $\times$ three population levels (non-infested and infested plants with 2 or 3 adults/m-number of adult specimens per linear meter) $\times$ three periods of infestation (6o days, from R5.1 to R9 stages; 30 days, from R6 to R9 stages; 21 days, from R7 to R9 stages) $\times$ four repetitions, totaling 72 trial plots. In the second trial, the same factorial arrangement was used with two stink bug species (C. impicticornis and $P$. guildinii) and different periods of infestation (61 days, from R5.1 to R9 stages; 51 days, from R5.3 to R9 stages; 39 days, from R6 to R9 stages). The following parameters were evaluated: foliar retention (Sosa-Gómez \& Moscardi 1995) and seed germination and damage. Seed damage was estimated by the tetrazolium test and classified from 1 to 8 (total number of damaged seeds, TZ 1-8) (França Neto et al 1998). Germination tests were performed using 50 seeds in each replication. The seeds were wrapped in wet paper towels and kept at $25^{\circ} \mathrm{C}$ for 5 days. Each treatment was replicated four times. The number of normal seedlings was recorded to calculate the germination percentage. The seeds $(n=50)$ from each plot were distributed on wet paper towels (with a mass of water of 2.5 -fold the mass of paper) and kept at $25^{\circ} \mathrm{C}$ in germination chambers under continuous light. Normal seedlings were counted after 5 days. Evaluations were replicated four times.

The data obtained was tested for normality (Shapiro \& Wilk 1965), independence of errors (Parente 1984), additivity (Tukey 1949), and homogeneity of variance (Burr \& Foster 1972) before ANOVA. ANOVA was followed by the Tukey's multiple comparison test $(p \leq 0.05)$. All analyses were carried using the Statistical Analysis System (SAS Institute 2009).

\section{Results and Discussion}

\section{Foliar retention}

Foliar retention in plants infested with 2 adults/m (number of adult specimens per linear meter) of $P$. guildinii ranged from 2.3 to 4.1 and represented up to 41 to $60 \%$ of green stems and were injuries caused during the longest period of infestation (61 days, from R5.1 to R9 stages). Foliar retention in plants infested with E. meditabunda and C. impicticornis 
ranged from 2.6 to 3.3 , indicating that they seem to have lower potential to cause foliar retention than $P$. guildinii. Studies performed with Euschistus heros (F.), N. viridula (L.), and $P$. guildinii indicated that the latter caused the highest foliar retention, followed by $N$. viridula and $E$. heros (Sosa-Gómez \& Moscardi 1995). Apparently, E. meditabunda and $C$. impicticornis caused foliar retention similar to the 1.9 to 3.1 observed for N. viridula (Sosa-Gómez \& Moscardi 1995) using the same visual score of the present work.

\section{Germination}

Seeds produced by plants infested with stink bugs during R5.1 stage exhibited lower germination when plants were infested with 2 and 3 adults/m of $P$. guildinii ( 89.0 and $81.5 \%$ ) and with 2 adults/m of $E$. meditabunda (85.3\%), as compared to seeds from plants with no infestation (96.5\%) (Table 1). When plants were exposed to 2 or 3 adults $/ m$ of E. meditabunda at the $\mathrm{R} 6$ stage, germination was reduced (84.7 and $88.0 \%)$ if compared to those with no infestation (99.0\%) (Table 1). During this growth stage, $P$. guildinii did not cause soybean seed quality losses, and no differences in germination were observed when compared to that observed for seeds from non-infested plants.

Injuries caused by E. meditabunda at a density of 3 adults/ $m$ during the shortest period of infestation (21 days at the R7R9 stages) reduced seed germination (68.7\%) when compared to the other treatments (Table 1). The apparent higher injury level caused by $E$. meditabunda could be due to uncontrolled variables in the field assay sown on November 12. During this growth stage, 2 or 3 adults $/ m$ of $P$. guildinii (83.0 and $88.5 \%$ ) caused significant reduction in seed germination when compared to the treatment without infestation (94.0\%) (Table 1).

The germination of soybean seeds was affected by the infestations at the $\mathrm{R} 7$ stage, although the period of plant exposure to stink bugs was only 21 days. However, in the study carried out by Panizzi et al (1979), infestations performed at the R7 stage ( 28 days) with 2 adults of $P$. guildinii per plant caused little effect on the germination (88.0\%) of soybean seeds. In a field cage trial conducted by Musser et al (2011), soybean plants were infested with $N$. viridula during the $\mathrm{R} 7$ stage, and a significant reduction in seed quality was observed with populations ranging from 9 to 15 adults $/ \mathrm{m}$.

Infestations at the R5.1 stage with 2 or 3 adults/m of C. impicticornis and $P$. guildinii caused significant reduction in germination of soybean seeds compared to the control (98.0 and 96.5\%). Piezodorus guildinii was also responsible for the highest reduction in germination (78.0 and $66.5 \%$ ), followed by $C$. impicticornis ( 89.0 and $80.0 \%$ ) (Table 2). Infestations at the $\mathrm{R} 5.3$ stage with 2 or 3 adults/m of C. impicticornis caused significant reduction in seed germination (76.5 and $87.5 \%$ ), as well as with P. guildinii (82.5 and $75.0 \%)$ if compared to the treatment without infestation (97.5 and 95.0\%) (Table 2).

Significant reduction in seed germination was also observed with infestations at the R6 stage with 2 or 3 adults/ $\mathrm{m}$ of $P$. guildinii (77.0 and $87.5 \%)$ and $C$. impicticornis $(80.7$ and $89.3 \%$ ) (Table 2).

\section{Seed damage}

The tetrazolium test showed that infestations with 2 or 3 adults/m of $P$. guildinii during the R5.1 stage caused

Table 1 Average percentage ( \pm SE) of soybean cv. NK 3363 seed germination in non-infested and infested plants with 2 or 3 adults/m of Edessa meditabunda and Piezodorus guildinii in different periods of infestation.

\begin{tabular}{|c|c|c|c|c|c|c|}
\hline $\begin{array}{l}\text { Period of } \\
\text { infestation }\end{array}$ & $\begin{array}{l}\text { Piezodorus } \\
\text { guildinii } \\
\text { Non-infested } \\
\text { (adults/m) }\end{array}$ & $\begin{array}{l}\text { Edessa } \\
\text { meditabunda } \\
\text { Non-infested } \\
\text { (adults/m) }\end{array}$ & $\begin{array}{l}\text { Piezodorus } \\
\text { guildinii } \\
2 \\
\text { (adults/m) }\end{array}$ & $\begin{array}{l}\text { Edessa } \\
\text { meditabunda } \\
2 \\
\text { (adults/m) }\end{array}$ & $\begin{array}{l}\text { Piezodorus } \\
\text { guildinii } \\
3 \\
\text { (adults/m) }\end{array}$ & $\begin{array}{l}\text { Edessa } \\
\text { meditabunda } \\
3 \\
\text { (adults/m) }\end{array}$ \\
\hline R5.1-R9 & $96.5 \pm 1.7$ & $96.5 \pm 1.5$ & $89.0 \pm 3.0$ & $85.3 \pm 2.9$ & $81.5 \pm 4.4$ & $97.0 \pm 1.0$ \\
\hline (6o days) & $A^{a, b} A^{c} a^{d}$ & $A A^{e} a^{f}$ & $A A B$ a & A B $a$ & $\mathrm{~B} B \mathrm{~b}$ & $\mathrm{~A} \mathbf{A} a$ \\
\hline R6-R9 & $94.0 \pm 3.5$ & $99.0 \pm 1.0$ & $87.0 \pm 3.7$ & $84.7 \pm 1.8$ & $91.5 \pm 1.5$ & $88.0 \pm 0.8$ \\
\hline (30 days) & $\mathrm{A} A \mathrm{a}$ & $\mathrm{A} A a$ & $\mathrm{~A} A \mathrm{a}$ & A B $a$ & $\mathrm{~A} A \mathrm{a}$ & A B $a$ \\
\hline R7-R9 & $94.0 \pm 3.2$ & $95.5 \pm 2.2$ & $83.0 \pm 1.4$ & $88.7 \pm 1.8$ & $88.5 \pm 1.3$ & $68.7 \pm 4.7$ \\
\hline (21 days) & $\mathrm{A} A \mathrm{a}$ & $\mathrm{A} \mathbf{A} a$ & $A B a$ & $\mathrm{~A} \mathbf{A} a$ & $\mathrm{~A} A B \mathrm{ab}$ & B B $b$ \\
\hline
\end{tabular}

\footnotetext{
${ }^{a}$ Means followed by the same upper case letters in the same line do not differ significantly by the Tukey test $(p>0.05)$.

${ }^{b}$ Upper case letters in the same line compared to stink bug species in each period of infestation and in each population level.

${ }^{c}$ Italicized upper case letters in the same line compared to $P$. guildinii in each period of infestation.

${ }^{d}$ Lower case letters in the same column compared to population level $\times P$. guildinii in the periods of infestation.

${ }^{\mathrm{e}}$ Bold upper case letters in the same line compared to $E$. meditabunda in each period of infestation.

${ }^{\mathrm{f}}$ Italicized lower case letters in the same column compared to population level $\times E$. meditabunda in the periods of infestation.
} 
Table 2 Average percentage ( \pm SE) of soybean cv. NK 3363 seed germination in non-infested and infested plants with 2 or 3 adults/m of Chinavia impicticornis and Piezodorus guildinii in different periods of infestation.

\begin{tabular}{|c|c|c|c|c|c|c|}
\hline $\begin{array}{l}\text { Period of } \\
\text { infestation }\end{array}$ & $\begin{array}{l}\text { Piezodorus } \\
\text { guildinii } \\
\text { Non-infested } \\
\text { (adults/m) }\end{array}$ & $\begin{array}{l}\text { Chinavia } \\
\text { impicticornis } \\
\text { Non-infested } \\
\text { (adults } / \mathrm{m} \text { ) }\end{array}$ & $\begin{array}{l}\text { Piezodorus } \\
\text { guildinii } \\
2 \\
\text { (adults/m) }\end{array}$ & $\begin{array}{l}\text { Chinavia } \\
\text { impicticornis } \\
2 \\
\text { (adults/m) }\end{array}$ & $\begin{array}{l}\text { Piezodorus } \\
\text { guildinii } \\
3 \\
\text { (adults/m) }\end{array}$ & $\begin{array}{l}\text { Chinavia } \\
\text { impicticornis } \\
3 \\
\text { (adults/m) }\end{array}$ \\
\hline R5.1-R9 & $98.0 \pm 0.8$ & $96.5 \pm 1.7$ & $78.0 \pm 4.2$ & $89.0 \pm 4.8$ & $66.5 \pm 3.8$ & $80.0 \pm 3.6$ \\
\hline (61 days) & $A^{a, b} A^{c} a^{d}$ & $\mathrm{~A} \mathbf{A}^{\mathrm{e}} a^{\mathrm{f}}$ & $A B a$ & $\mathrm{~A} \mathbf{A B} a$ & $A B b$ & A B $a$ \\
\hline R5.3-R9 & $97.5 \pm 1.0$ & $95.0 \pm 1.3$ & $82.5 \pm 3.4$ & $76.5 \pm 6.0$ & $75.0 \pm 5.3$ & $87.5 \pm 4.1$ \\
\hline (51 days) & $\mathrm{A} A \mathrm{a}$ & $\mathrm{A} A a$ & $A B a$ & A B $b$ & $A B a b$ & $\mathrm{~A} \mathbf{A B} a$ \\
\hline R6-R9 & $97.5 \pm 1.0$ & $97.5 \pm 0.9$ & $77.0 \pm 8.4$ & $80.7 \pm 8.7$ & $87.5 \pm 3.7$ & $89.3 \pm 2.9$ \\
\hline (39 days) & $\mathrm{A} A \mathrm{a}$ & $\mathrm{A} \mathbf{A} a$ & $A B a$ & A B $a b$ & $A A B$ a & $\mathrm{A} \mathbf{A B} a$ \\
\hline
\end{tabular}

${ }^{a}$ Means followed by the same upper case letters in the same line do not differ significantly by the Tukey test $(p>0.05)$.

${ }^{b}$ Upper case letters in the same line compared to stink bug species in each period of infestation and in each population level.

${ }^{c}$ Italicized upper case letters in the same line compared to $P$. guildinii in each period of infestation.

${ }^{d}$ Lower case letters in the same column compared to population level $\times P$. guildinii in the periods of infestation.

${ }^{\text {e }}$ Bold upper case letters in the same line compared to $C$. impicticornis in each period of infestation.

${ }^{\mathrm{f}}$ Italicized lower case letters in the same column compared to population level $\times C$. impicticornis in the periods of infestation.

expressive seed injury ( 22.6 and $25.0 \%$, TZ 1-8), significantly different from $E$. meditabunda and the treatment without infestation (Table 3).

Infestations at the R6 stage with 3 adults/m of E. meditabunda caused significant seed injury $(23.0 \%$, TZ 1-

8) compared to the treatment with no infestation and P. guildinii (7.4\%) (Table 3). Edessa meditabunda also caused the highest number of damaged seeds when infesting the R7 stage (Table 3).

At R7 stage, $P$. guildinii and $E$. meditabunda caused similar losses of seeds (TZ1-8). In both cases, seed losses were much higher than those observed in non-infested plants (Table 3). These results disagree with those reported by Panizzi et al (1979), who indicated that 2 adults/m of $P$. guildinii at the R7

Table 3 Average $( \pm \mathrm{SE})$ number of soybean cv. NK 3363 seeds damaged by stink bugs, estimated by tetrazolium test, in non-infested and infested plants with 2 or 3 adults/m of Edessa meditabunda and Piezodorus guildinii in different periods of infestation.

\begin{tabular}{|c|c|c|c|c|c|c|}
\hline $\begin{array}{l}\text { Period of } \\
\text { infestation }\end{array}$ & $\begin{array}{l}\text { Piezodorus } \\
\text { guildinii } \\
\text { Non-infested } \\
\text { (adults/m) }\end{array}$ & $\begin{array}{l}\text { Edessa } \\
\text { meditabunda } \\
\text { Non-infested } \\
\text { (adults/m) }\end{array}$ & $\begin{array}{l}\text { Piezodorus } \\
\text { guildinii } \\
2 \\
\text { (adults/m) }\end{array}$ & $\begin{array}{l}\text { Edessa } \\
\text { meditabunda } \\
2 \\
\text { (adults/m) }\end{array}$ & $\begin{array}{l}\text { Piezodorus } \\
\text { guildinii } \\
3 \\
\text { (adults/m) }\end{array}$ & $\begin{array}{l}\text { Edessa } \\
\text { meditabunda } \\
3 \\
\text { (adults } / \mathrm{m} \text { ) }\end{array}$ \\
\hline \multirow{3}{*}{$\begin{array}{l}\text { R5.1-R9 } \\
\text { (6o days) }\end{array}$} & $0.0 \pm 0.0$ & $0.0 \pm 0.0$ & $11.3 \pm 3.9$ & $3.3 \pm 1.3$ & $12.5 \pm 2.3$ & $3.8 \pm 2.5$ \\
\hline & (0.0\%) & (0.0\%) & (22.6\%) & $(6.6 \%)$ & $(25.0 \%)$ & (7.6\%) \\
\hline & $A^{a, b} A^{c} a^{d}$ & $A A^{e} a^{f}$ & $\mathrm{~B} \mathrm{~B} \mathrm{a}$ & $\mathrm{A} \mathbf{A} a$ & $\mathrm{~B} B \mathrm{~b}$ & $\mathrm{~A} \mathbf{A} a$ \\
\hline \multirow{3}{*}{$\begin{array}{l}\text { R6-R9 } \\
\text { (30 days) }\end{array}$} & $0.8 \pm 0.8$ & $0.0 \pm 0.0$ & $5.7 \pm 1.8$ & $4.7 \pm 0.7$ & $3.7 \pm 0.7$ & $11.5 \pm 3.0$ \\
\hline & $(1.6 \%)$ & (0.0\%) & (11.4\%) & (9.4\%) & $(7.4 \%)$ & (23.0\%) \\
\hline & $\mathrm{A} A \mathrm{a}$ & $\mathrm{A} \mathbf{A} a$ & $\mathrm{~A} A \mathrm{a}$ & $\mathrm{A} \mathbf{A B} a$ & $\mathrm{~A} A \mathrm{a}$ & B B $b$ \\
\hline \multirow{3}{*}{$\begin{array}{l}\text { R7-R9 } \\
\text { (21 days) }\end{array}$} & $0.0 \pm 0.0$ & $0.0 \pm 0.0$ & $6.7 \pm 1.9$ & $17.0 \pm 3.2$ & $11.5 \pm 2.0$ & $20.7 \pm 3.7$ \\
\hline & (0.0\%) & (0.0\%) & $(13.4 \%)$ & (34.0\%) & (23.0\%) & $(41.4 \%)$ \\
\hline & $\mathrm{A} A \mathrm{a}$ & $\mathrm{A} \mathbf{A} a$ & $A A B$ a & B B $b$ & $A B b$ & B B C \\
\hline
\end{tabular}

Damaged seeds classified from 1 to 8 (França Neto et al 1998).

${ }^{a}$ Means followed by the same upper case letters in the same line do not differ significantly by the Tukey test $(p>0.05)$.

${ }^{b}$ Upper case letters in the same line compared to stink bug species in each period of infestation and in each population level.

${ }^{c}$ Italicized upper case letters in the same line compared to $P$. guildinii in each period of infestation.

${ }^{d}$ Lower case letters in the same column compared to population level $\times P$. guildinii in the periods of infestation.

${ }^{\mathrm{e}}$ Bold upper case letters in the same line compared to $E$. meditabunda in each period of infestation.

${ }^{\mathrm{f}}$ Italicized lower case letters in the same column compared to population level $\times E$. meditabunda in the periods of infestation. 
stage cause seed losses (4.0\%) similar to that observed in non-infested plants (4.0\%).

The tetrazolium test in the second trial indicated that $P$. guildinii was the most harmful stink bug species at both infestations levels ( 2 or 3 adults/m) at the R5.1 stage (Table 4), but injury caused to the seeds (TZ 1-8) due to infestations with 2 or 3 adults/m of $P$. guildinii and $C$. impicticornis at the R5.3 stage were similar (Table 4 ).

In the period of infestation from R6 to R9, P. guildinii injured a higher number of seeds $(76.6 \%, \mathrm{TZ} 1-8)$ than $C$. impicticornis when infesting plants at 2 adults/m (Table 4). In the present study, P. guildinii, E. meditabunda, and C. impicticornis affected germination. Nevertheless, the injury caused by infestations with 3 adults/m of $P$. guildinii was higher (66.5\% of germination) at the R5-R9 growing stage. Panizzi et al (1979) reported that 2 adults/m of $P$. guildinii infesting soybean plants at the R1-R8 stage also reduced germination (38.0\%). The highest losses in germination were registered for the longest periods of infestation (60 and 61 days) from stages R5.1 to R9. The R5 stage is considered one of the most susceptible to stink bug attack (Galileo \& Heinrichs 1979, Panizzi et al 1979, CorrêaFerreira \& Panizzi 1999).

Stink bug infestations at the R7 stage have only been carried out in Brazil by Panizzi et al (1979), and they did not observe significant differences in germination. We observed that the R7 stage can be considered a critical period for stink bug infestation. At this stage, the loss of seed germination caused by infestations with 3 adults/m of $E$. meditabunda was higher than that caused by 3 adults/m of $P$. guildinii, whereas the losses caused by 2 adults/m of $P$. guildinii was significantly greater than that of $E$. meditabunda.

The differences observed in the injury caused by E. meditabunda and $P$. guildinii might be related to the strength of the enzyme in their saliva, length of stylets, and feeding preference. Once $E$. meditabunda prefers soybean stems to pods (Galileo \& Heinrichs 1979), this stink bug species needs to feed longer in order to get enough nutrients for its development (Silva et al 2012). Further, the stylet of E. meditabunda is shorter than that of $P$. guildinii (Panizzi \& Machado-Neto 1992); thus, the former species causes more superficial injury to the seeds, whereas the latter is more harmful to the seeds. Nevertheless, more studies are necessary to better understand these differences.

Piezodorus guildinii and C. impicticornis exhibited higher potential to cause foliar retention. Significant losses of soybean seed quality (germination, TZ 1-8) were caused by C. impicticornis at the R6 stage, E. meditabunda in the shortest period of infestation from R7 to R9 (20 days), and P. guildinii in the initial period of infestation from R5.1 to R9.

The variability of injury observed in different sowing periods does not permit to conclude which species, E. meditabunda or C. impicticornis, was the most harmful. The damage caused by $P$. guildinii was higher in the second sowing period, probably because the cultivar was sown at

Table 4 Average ( \pm SE) number of soybean cv. NK 3363 seeds damaged by stink bugs, estimated by tetrazolium test, in non-infested and infested plants with 2 or 3 adults/m of Chinavia impicticornis and Piezodorus guildinii in different periods of infestation.

\begin{tabular}{|c|c|c|c|c|c|c|}
\hline $\begin{array}{l}\text { Period of } \\
\text { infestation }\end{array}$ & $\begin{array}{l}\text { Piezodorus } \\
\text { guildinii } \\
\text { Non-infested } \\
\text { (adults/m) }\end{array}$ & $\begin{array}{l}\text { Chinavia } \\
\text { impicticornis } \\
\text { Non-infested } \\
\text { (adults/m) }\end{array}$ & $\begin{array}{l}\text { Piezodorus } \\
\text { guildinii } \\
2 \\
\text { (adults/m) }\end{array}$ & $\begin{array}{l}\text { Chinavia } \\
\text { impicticornis } \\
2 \\
\text { (adults/m) }\end{array}$ & $\begin{array}{l}\text { Piezodorus } \\
\text { guildinii } \\
3 \\
\text { (adults/m) }\end{array}$ & $\begin{array}{l}\text { Chinavia } \\
\text { impicticornis } \\
3 \\
\text { (adults } / \mathrm{m} \text { ) }\end{array}$ \\
\hline \multirow{3}{*}{$\begin{array}{l}\text { R5.1-R9 } \\
\text { (61 days) }\end{array}$} & $0.0 \pm 0.0$ & $0.0 \pm 0.0$ & $31.8 \pm 5.4$ & $15.8 \pm 2.8$ & $34.0 \pm 4.2$ & $19.5 \pm 4.6$ \\
\hline & (0.0\%) & (0.0\%) & (63.6\%) & (31.6\%) & (68.0\%) & (39.0\%) \\
\hline & $A^{a, b} A^{c} a^{d}$ & $\mathrm{~A} \mathbf{A}^{\mathrm{e}} a^{\mathrm{f}}$ & $\mathrm{B} B \mathrm{a}$ & A B $a$ & $B B b$ & $\mathrm{~A} B \mathrm{~B}$ \\
\hline \multirow{3}{*}{$\begin{array}{l}\text { R5.3-R9 } \\
\text { (51 days) }\end{array}$} & $0.0 \pm 0.0$ & $0.0 \pm 0.0$ & $27.3 \pm 2.7$ & $19.3 \pm 3.9$ & $29.0 \pm 6.1$ & $21.5 \pm 4.6$ \\
\hline & (0.0\%) & (0.0\%) & (54.6\%) & (38.6\%) & (58.0\%) & $(43.0 \%)$ \\
\hline & $\mathrm{A} A \mathrm{a}$ & $\mathrm{A} \mathbf{A} a$ & $A B a$ & A B $a$ & $A B b$ & A B $a$ \\
\hline \multirow{3}{*}{$\begin{array}{l}\text { R6-R9 } \\
\text { (39 days) }\end{array}$} & $0.0 \pm 0.0$ & $0.0 \pm 0.0$ & $38.3 \pm 2.6$ & $27.0 \pm 6.6$ & $9.3 \pm 2.4$ & $12.0 \pm 3.5$ \\
\hline & $(0.0 \%)$ & $(0.0 \%)$ & $(76.6 \%)$ & (54.0\%) & (18.6\%) & $(24.0 \%)$ \\
\hline & $\mathrm{A} A \mathrm{a}$ & $\mathrm{A} \mathbf{A} a$ & $\mathrm{~B} B \mathrm{a}$ & A B $a$ & $\mathrm{~A} A \mathrm{a}$ & $\mathrm{A} \mathbf{A} a$ \\
\hline CV (\%) & 45.98 & & & & & \\
\hline
\end{tabular}

Damaged seeds classified from 1 to 8 (França Neto et al 1998).

${ }^{a}$ Means followed by the same upper case letters in the same line do not differ significantly by the Tukey test ( $\left.p>0.05\right)$.

${ }^{\mathrm{b}}$ Upper case letters in the same line compared to stink bug species in each period of infestation and in each population level.

${ }^{\mathrm{c}}$ Italicized upper case letters in the same line compared to $P$. guildinii in each period of infestation.

${ }^{d}$ Lower case letters in the same column compared to population level $\times P$. guildinii in the periods of infestation.

e Bold upper case letters in the same line compared to $C$. impicticornis in each period of infestation.

${ }^{\mathrm{f}}$ Italicized lower case letters in the same column compared to population level $\times$ C. impicticornis in the periods of infestation. 
the end of the recommended period. It is advisable to carry out further studies under controlled conditions to determine differences in the injuries caused by $E$. meditabunda and C. impicticornis.

Acknowledgments The authors are thankful to Dr. Jocelia Grazia for the identification of the stink bugs. The authors are also grateful to the Conselho Nacional de Desenvolvimento Científico e Tecnológico (CNPq) for the scholarship granted to PEH and Universidade Estadual de Ponta Grossa and Embrapa Soja for providing the financial resources and structure to carry out this research. This study is approved for publication by the Editorial Board of Embrapa Soja as manuscript 10/2013.

\section{References}

Burr IW, Foster LA (1972) A test for equality of variances, Mimeo series no. 282. University of Purdue, West Lafayette, $26 \mathrm{p}$

Corrêa-Ferreira BS, Panizzi AR (1999) Percevejos da soja e seu manejo. Embrapa Soja, Londrina, $45 \mathrm{p}$

Depieri RA, Panizzi AR (2011) Duration of feeding and superficial and indepth damage to soybean seed by selected species of stink bugs (Heteroptera: Pentatomidae). Neotrop Entomol 40:197-203

França Neto JB, Krzyzanowski FC, Costa NP (1998) O teste de tetrazólio em sementes de soja. Embrapa Soja, Londrina, $72 \mathrm{p}$

Galileo MHM, Heinrichs EA (1979) Danos causados a soja em diferentes níveis e épocas de infestação, durante o crescimento. Pesq Agrop Brasileira 14:279-282

Golin V, Loiácono MS, Margaría CB, Aquino DA (2011) Natural incidence of egg parasitoids of Edessa meditabunda (F.) (Hemiptera: Pentatomidae) on Crotalaria spectabilis in Campo Novo do Parecis, MT, Brazil. Neotrop Entomol 40:617-618

Krinski D (2013) First report of phytophagous stink bug in chicory crop. Cienc Rural 43:42-44

Krinski D, Pelissari TD (2012) Occurrence of the stinkbug Edessa meditabunda F. (Pentatomidae) in differents cultivars of lettuce Lactuca sativa L. (Asteraceae) Biosci J 28:654-659

Krinski D, Favetti BM, Butnariu AR (2012) First record of Edessa meditabunda (F.) on lettuce in Mato Grosso State, Brazil. Neotrop Entomol 41:79-80

Musser FR, Catchot AL, Gibson BK, Knighten KS (2011) Economic injury levels for southern green stink bugs (Hemiptera: Pentatomidae) in R7 growth stage soybeans. Crop Prot 30:63-69
Panizzi AR (2002) Stink bugs on soybean in Northeastern Brazil and a new record on the Southern green stink bug, Nezara viridula (L.) (Heteroptera: Pentatomidae). Neotrop Entomol 31: 331-332

Panizzi AR, Bueno AF, Silva FAC (2012) Insetos que atacam vagens e grãos. In: Hoffmann-Campo CB, Corrêa-Ferreira BS, Moscardi F (eds) Soja: manejo integrado de insetos e outros artrópodes-praga. Embrapa, Brasília, pp 335-420

Panizzi AR, Machado-Neto E (1992) Development of nymphs and feeding habits of nymphal and adult Edessa meditabunda (Heteroptera: Pentatomidae) on soybean and sunflower. Ann Entomol Soc Am 85: 477-481

Panizzi AR, Smith JG, Pereira LAG, Yamashita J (1979) Efeitos dos danos de Piezodorus guildinii (Westwood, 1837) no rendimento e qualidade da soja. An Semin Nac Pesqui Soja 1 Lond PR 2:59-78

Parente RCP (1984) Aspectos da análise de resíduos. Master's Dissertation, Escola Superior de Agricultura "Luiz de Queiroz", Universidade de São Paulo, Brasil

Ritchie SW, Hanway JJ, Thompson HE (1982) How a soybean plant develops. Iowa State University of Science and Technology, Cooperative Extension Service, Ames, $20 \mathrm{p}$ (Special Report, 53)

SAS Institute (2009) SAS/STAT: user's Guide, Version 9.2. SAS Institute, Cary, $7869 p$

Schwertner CF, Grazia J (2007) O gênero Chinavia Orian (Hemiptera, Pentatomidae, Pentatominae) no Brasil, com chave pictórica para os adultos. Rev Bras Entomol 51:416-435

Shapiro SS, Wilk MB (1965) An analysis of variance test for normality (complete samples). Biometrika 52:591-611

Silva FAC, Silva JJ, Depieri RA, Panizzi AR (2012) Feeding activity, salivary amylase activity, and superficial damage to soybean seed by adult Edessa meditabunda (F.) and Euschistus heros (F.) (Hemiptera: Pentatomidae). Neotrop Entomol 41:386-390

Sosa-Gómez DR, Moscardi F (1995) Retenção foliar diferencial em soja provocada por percevejos (Heteroptera: Pentatomidae). An Soc Entomol Bras 24:401-404

Sosa-Gómez DR, Silva JJ (2010) Neotropical brown stink bug (Euschistus heros) resistance to methamidophos in Paraná, Brazil. Pesq Agrop Brasileira 45:767-769

Tukey JW (1949) One degree of freedom for non-additivity. Biometrics 5: 232-242

Yorinori JT (1996) Cancro da haste da soja: epidemiologia e controle. Londrina, EMBRAPA-CNPSo, 75p. (Circular Técnica, 14).

Yukawa J, Kiritani K, Gyoutoku N, Uechi N, Yamaguchi D, Kamitani S (2007) Distribution range shift of two allied species, Nezara viridula and $N$. antennata (Hemiptera: Pentatomidae), in Japan, possibly due to global warming. Appl Entomol Zool 42:205-215 